\title{
The Survival Force of Literature
}

\section{Michal Přibáň a kolektiv, Český literární samizdat 1949-1989. Edice, časopisy, sborniky. Praha: Academia-Ústav pro českou literaturu AV ČR, 2018, pp. 612.}

\begin{abstract}
Kowalska-Nadolna Urszula, The Survival Force of Literature. "Poznańskie Studia Slawistyczne" 19. Poznań 2020. Publishing House of the Poznań Society for the Advancement of the Arts and Sciences, Adam Mickiewicz University, pp. 391-404. ISSN 2084-3011.

The following review article brings a presentation of the published in 2018 encyclopaedia of Czech literary samizdat. The analysed publication consists of two parts - a comprehensive introduction discussing the question of independent literary culture in Czechoslovakia under communist regime pressure and an entry section with more than 300 entries about Czech independent self-publishing activities. The presentation of the following book provokes the need to re-examine the phenomenon of Czech samizdat, reflecting on its chronological framework, definition, meaning and role in creating and keeping alive an independent culture in the era of domination of the communist regime (1948-1989).
\end{abstract}

Keywords: Czech dissent; self-publishing in Czechoslovakia; wild samizdat; samizdat; Czech independent culture of the communist period

Literature cannot be eradicated. It is not doing very well in the catacombs, but this is a training of persistence. [...] At least all those, who do not carry it in a heart as the only reason for existence, will leave. (Jan Hanč [trans. U.K.-N.])

The Czechs seem to expect from journalists and writers things, in which failed so far even the Blaník knights. (Petr Pithart [trans. U.K.-N.])

The prominent Czech writer, journalist, and diplomat Jiří Gruša attributed to the Czech samizdat the role of a ventilator, enabling its authors 
any movement or action. He saw in alternative Czech culture a counterbalance to the literary and artistic "glaciation", typical for the cultural publishing policy of the communist regime. "This kind of ubiquitous death has established a new source of heat that has come to be called dissent" (cf. Hvížd'ala, 2011, 126). In the "timeless time" of "normalization" (it was Petr Pithart who wrote about čas bezčasu in the context of this historical period, cf. Pithart, 2009, 14), men of literature, men of letters (cf. Možný, 2009, 53) became the pillar of dissident movement. They were perceiving, according to Václav Havel, "the socio-hygienic meaning of the word." Thanks to their actions, the "facade of official culture" existing in communist Czechoslovakia, as well as in Poland, has ceased to obscure the solidly constructed "large buildings of unofficial culture" (cf. Barańczak, 2009, 382-383).

In 2018 Ústav pro českou literaturu AV ČR (The Institute of Czech Literature of the CAS) in cooperation with Academia publishing house published a study that provides penetrating insight into this quite "large building". It returns thereby to the subject of independent Czech literature before 1989, as well as many valuable studies published during recent years, presenting the issues of Czech samizdat and dissident circles which constituted the world of independent Czech culture in the second half of the $20^{\text {th }}$ century. ${ }^{1}$ However, the encyclopaedia, prepared by the research team led by Michal Přribán̆, is an exceptional publication which certainly deserves attention and appreciation also in a foreign research space. It seems, that it is the first work thematically considered in such a way - the authors dealt not only with the most well-known and well-described in scientific literature self-publishing phenomena (just to mention Edice Petlice, Edice

${ }^{1}$ It is impossible to list here all relevant publications about independent Czech culture of the communist regime period (most of the titles are to be found in the reviewed book). However, it is worth to note that last years brought interesting research studies for English speaking readers, just to mention few of them: Bolton, J. (2012). Worlds of Dissent: Charter 77, the Plastic People of the Universe, and Czech Culture Under Communism. London: Harvard University Press; Machovec, M. (ed.) (2018). Views from the Inside Czech Underground Literature and Culture (1948-1989): Manifestoes - Testimonies - Documents. Prague: Charles University-Karolinum Press; Glanc, T. (ed.) (2018). Samizdat: Past \& Present. Prague: Institute of Czech Literature-Karolinum Press; Machovec, M. (2019). Writing Underground Reflections on Samizdat Literature in Totalitarian Czechoslovakia. Prague: Karolinum Press. 
Expedice or the magazines such as, for example, "Revolver Revue"), but first and foremost collected many unknown data on a number of local, small editions and magazines devoted to broadly defined literary culture.

The first part of the book (quite modestly titled by the authors "Introduction" [cf. Úvodem, pp. 11-93]) provides a comprehensive study of independent literary culture in Czechoslovakia after World War II. The value of this introductory study on existence of the so-called literary samizdat cannot be overestimated, since its authors managed to gather the most important historical, sociological, cultural, literary and linguistic information related to the independent Czechoslovak culture, previously dispersed in separate publications or completely absent from the scientific discourse. The authors, with enviable respect and caution, consider terminology, precisely defining the scope of their interests, while being aware of the pitfalls lurking in this precision. Since it is difficult to conclude that the encyclopaedia of literary samizdat concerns only literature and only samizdat, it is certainly impossible to separate the title term from non-literary artistic and journalistic activities, or from the exile literary circles, strongly associated with the domestic independent artistic scene.

The essence of the following publication is quite well visible just after reading its first pages, where the authors summarize a discussion on the term samizdat, borrowed from the Russian language, but, especially in the period between the Prague Spring and the Velvet Revolution, wellestablished in the Czech context. As an important "component" of the phenomenon of samizdat (apart from its obvious "self-sufficiency", existing and evolving regardless of techniques and possibilities of official publishing institutions), its belonging to an alternative culture and being in close relations with the so-called political dissent are also discussed in the encyclopaedia (which is why, among other, it is not appropriate to talk about samizdat in the context of independent works published in The Protectorate of Bohemia and Moravia, cf. p. 14).

The appearance of the term itself directs to 1949 (the person responsible for its existence is considered to be the poet Nikolaj Glazkov, who released his original manuscript, for political reasons officially "uneditable", with the note "samsebjaizdat" [p. 13]). In Czechoslovakia, the term settled mainly in the context of literature of the 1970s and 1980s, but it also appears in relation to independent works edited after February 1948 (with the 
most famous underground editions Pulnoc established by Egon Bondy and Explosionalismus by Vladimír Boudník). However, an eminent researcher of the Czech underground and independent culture, Martin Machovec, suggests using the term protosamizdat in the context of literary activities of this period (cf. Machovec, 2009, 1-26). The terminological balancing between these two terms does not change the fact, that none of them was used in the 1950s in reference to independent Czechoslovak literature. The description samizdat had to wait for its popularity until the 1970 s - on the one hand the darkest, on the other hand perhaps the most creative period in the $20^{\text {th }}$ century history of Czechoslovak culture. The authors note here an interesting sociological issue, emphasizing that at first the usage of the Russian term in the context of literature or, more broadly, culture, which reacted critically to Soviet domination, was something difficult to accept for many independent publishers and writers (cf. p. 14).

Besides samizdat, which eventually has been approved by the critics as the appropriate literary term, it is worth mentioning some of the alternative terminological ideas, such as: literatura ineditni (literally: "unedited" or "uneditable" literature), neoficiální (unofficial), nezávislá (independent), opoziční (dissident), paralelní (parallel) or even petliční (allusive to the name of the most famous Czech independent publishing house Edice Petlice [Edition Padlock]). ${ }^{2}$ In the discussion about the appropriate name, the "second circulation" (cf. 14-15), known from the Polish context, or the concept of literatura strojpisná ("typewritten literature"), referring to the techniques of the texts "production", were also considered.

The discussion, aimed at establishing the appropriate terminology, lasted for many years and it probably would not be an exaggeration to say, that in some circles of literary scholars it lasts till now. Petr Fidelius, in the article published in 1981, wrote about these terminological difficulties as follows:

We are facing quite a practical question: how to name properly this awakening, independent culture. Independent? Parallel? Unofficial? Or just the "second"? [...] The fluctuating of current meaning proves, inter alia, that we are not advanced enough in

${ }^{2}$ In the biggest and the most famous samizdat self-publisher Edice Petlice, almost 400 titles were published between 1972-1989. Its name alluded ironically to the official publishing house Klíč [The Key]. 
the reflection on our activities; none of the existing terms fully reflects the essence of the phenomenon - it is probably also due to the fact, that the very essence of what we are trying to do is not fully defined (Fidelius, 2009, 2 [trans. U.K.-N.]).

On the other hand, Tomáš Vrba emphasized, for example, the need to distinguish samizdat from unofficially published literature, defining the first one (in relation to the original meaning) as anonymously typed versions of texts, "without editorial and typographic interferences and publishing ambitions" (Vrba, 2001, 266). It seems to be an extremely strict criterion in the context of often particularly editorially well prepared and graphically designed editions of independent Czech literature. ${ }^{3}$ A slightly different understanding of samizdat is evoked by Jiří Gruntorád, quoted by the authors of the encyclopaedia. He suggests differentiating "publishing" and "rewriting" texts, for the effects of this second activity, aspiring to provide private circulation of officially prohibited publications, he proposes the term divoky' samizdat ("wild samizdat") (p. 15). Moreover, it seems that discovering and describing the phenomenon of the "wild samizdat", which for many years has remained on the margins of scientific interest, becomes the main task for the authors of the encyclopaedia in question.

Although Czech independent culture of the period of communist regime have been already discussed in a great number of books and articles, some issues seem to require further research - one of them is the coexistence of three kinds of "literary circulations" and the need to analyse them as an integral phenomenon, against the quite understandable, resulting from significant differences, inclinations to isolate them. The belief that samizdat, official literature and exile literature should be perceived as elements that co-create one Czech culture, is often accompanied by the postulate that the activities of exile or samizdat circles should not be called the "second" or "alternate" culture. Another problem is the question of interpretation of literary texts regarding this cultural stratification - literary criticism of the 1970s and 1980s warned against unequivocal ennoblement

\footnotetext{
${ }^{3}$ Relatively small editions (especially in comparison with Polish underground publishing) prepared by Czech independent self-publishers, very often went hand in hand with extremely careful graphic design of the publication. Thanks to supplementing entries with rich photographic documentation, the authors of Literárni samizdat also present the aesthetic aspect of independent culture.
} 
of the so-called "uneditable" texts. In turn, some examples of officially published texts (written, for instance, by Bohumil Hrabal, Vladimír Parál or Ladislav Fuks) are enough to confirm the necessity of separating according to Jiří Gruša, "'Literature' created by clerks and writers-policemen from official literature" (Jagodziński, 200, 56). Or, as Ota Filip claimed, understanding dissent as an expression of civic courage, not as an aesthetic-literary category (cf. Filip, 2008). ${ }^{4}$

An attempt to point out the univocal definition of samizdat is difficult if not impossible - because of the both technical and chronological criteria. The question of the time frame of samizdat remains open - this term is quite often limited to the period of the so-called normalization, however, it may also "include" literature published during the entire period of the communist regime, and even after regaining political and cultural independence in 1989 , in relation to the new socio-cultural phenomena. ${ }^{5}$ The authors of the encyclopaedia in question unlock this terminological impasse by suggesting a definition of samizdat adopted for the purposes of their scientific research and compatible with the methodology of their work, as following:

Therefore, we do not limit the interpretation of the term samizdat to the activities of publishers who have maintained a high level of book culture [...], but include all independent literature of this historical period [1949-1989 - U.K.-N.] that found itself in conflict with the cultural policy of the totalitarian state and was despite the danger of repression, spread thanks to civic self-help (p. 16 [trans. U.K.-N.; bold the authors of quotation]).

Separate attention should be paid to the title epithet literárni ("literary") - the authors admit that it is almost impossible to distinguish

${ }^{4}$ Three decades that have passed since the beginning of the political transformation are conducive to an in-depth analysis and revision of the ways of presenting Czech unofficial culture. New questions arise - they are mainly concerning the content and topics absent in the independent "second circulation" or some inner conflicts among the representatives of dissident community. However, the authors of Literárni samizdat focus on a thorough, highly objective commentary based on historical sources collected mainly in the archives of the Libri Prohibiti Library, The Czecho-Slovak Documentation Centre for Independent Literature and private collections of witnesses of the era.

${ }^{5}$ The authors of the encyclopaedia point out following terms present in contemporary academic and literary criticism discourse: polosamizdat (half-samizdat), semi-samizdat, osvobozený samizdat (liberated samizdat), postsamizdat, nový samizdat (new samizdat), neosamizdat, novodobý samizdat (contemporary samizdat), moderní samizdat (modern samizdat). 
something like "pure literary samizdat." The original idea of the publication was to describe the publishing activity focused on literary fiction and literary criticism. As it turned out, this was impossible to achieve due to the specificity of independent editorial activity, emerging from the very essence of independent culture.

After all, a narrow publishing specialization would not correspond to the prevailing social conditions. Publishers, authors, and readers shared a basic starting point, and most of them saw samizdat as a rebellion against the power suppressing both: free creation and discussion without any boundaries. There were not many sources of independent information and ideologically unmarked texts, the circles of their colporteurs and recipients were permeating. Historical, philosophical, theological, and artistic publications appeared in publishers and editions with a predominant fiction production, and similar professional openness was also characteristic for the editors of the relevant periodicals (p. 21 [trans. U.K.-N.]).

In the introduction, the reader can also find, beyond reflections on the very essence of samizdat and discussions on its definition in the Czech and global context, terminological thoughts related to the publishing nomenclature typical of the discussed historical and literary period, the typology of periodicals (considering the place of their publication) or a chronological overview of independent publishing activity (divided into sections devoted to: post-February period, the beginnings of 1950s, independent Czech culture of 1960s, and the era of "normalization;" the last part in this chapter refers to the second half of 1980s). Obviously, the most extensive fragments of the introductory study preluding the encyclopedic part of the publication, are devoted to the times of "normalization." This is the period of, on the one hand - the most severe repressions towards representatives of independent culture (according to current law, "anti-socialist publishing activity" was one of the most serious crimes against the state), on the other hand - a significant revival of the underground publishing "market" and the formation of democratic opposition centered largely around the famous Charter 77 . The time between 1969-1971 was a stage of an absolute obstructing Czech independent culture and formed new, although in many aspects well known from the 1950s, "normalization" conditions. The task of "reviving the cultural cemetery", according to Heinrich Böll who coined this phrase to describe the realities of the period shortly after the invasion of the Warsaw Pact forces, began seriously with the establishment of Edice Petlice. 
The "specter of dissidents" spreading in the 1970s, about which Václav Havel wrote in his canonical essay dedicated to Jan Patočka, faces the task of raising an alternative culture, thus ensuring the ideological independence of society and rehabilitating such values as trust, honesty, responsibility and solidarity. "Second-class citizens," as Havel defined dissidents, found the answer to the moral crisis of society and disappointment with the failure of the Prague Spring - it sounds trivial, although in the context of a system based on lies also boldly: the necessity of living in truth.

Detailed study on the independent literary scene in the $2^{\text {nd }}$ half of the $20^{\text {th }}$ century, prepared by Michal Přibáň's team, also includes an explanation of such phenomena as šedá zóna ("grey zone") ${ }^{6}$ or samizdat s razitkem ("samizdat with a stamp"). ${ }^{7}$ The publication discusses numerous literary samizdat periodicals, editions and collective volumes (which are particularly rare among independent publications), as well as the methods of preparing samizdat publications, including graphic and editorial side of printed texts or the techniques of copying and reproducing them (from classic typewriters to their more advanced electronic versions or mimeographs quite commonly used for the production of Polish "self-publishing" materials, in Czechoslovakia remaining rather rare).

Interesting information, so far infrequently presented in scientific literature, is also provided by the section devoted to the economic aspects of samizdat production, which would be practically impossible without the support of foreign institutions, such as Nadace Charty 77 (The Charter 77 Foundation), founded in Sweden by František Janouch, or Vzdělávací nadace Jana Husa (The Jan Hus Educational Foundation). A separate, but also fascinating chapter in the history of the Czech literary samizdat as well as in the reviewed publication concerns such problems as distribution

${ }^{6}$ This is another term that causes some interpretative problems. Šeda zóna could be described as a community of people who seemingly remained loyal to the regime or declared apoliticality, which, however, did not mean absolute loyalty and lack of interest in politics. Šedá zóna in the field of literature included artists, who did not receive support from the regime, but their work was "tolerated" (cf. p. 41).

${ }^{7}$ This term refers to the problem rarely described in scientific literature, that is, publications that have been officially approved for distribution, even though their content has often been in conflict with the official cultural policy (for more information v. pp. 37-39). 
of self-published materials, legal aspects of publishing and repressions against people involved in "self-publishing" process with particular emphasis on the beginnings of Charter 77, as a significant breakthrough in the history of Czech samizdat (activities aimed at strengthening the independent culture intensified at that time, as well as harassments and repressions against people involved in "anti-state activities", cf. pp. 67-78). The commentary about the Czech literary samizdat ends with the subject of the contacts between some independent domestic circles and the world behind the Iron Curtain. Speaking of samizdat, it is impossible to ignore the existence of the largest emigration publishing houses that dealt with distribution of independent Czech literature in the West (including first of all Zdena Salivarová's and Josef Škvorecký's Sixty-Eight Publishers in Toronto and Adolf Müller's Index in Cologne), the networks of couriers, the logistics and technical assistance from abroad (with a great role of Jan Kavan), the support from Western diplomats, the cooperation with opposition groups from neighboring countries, and the support from exile cultural institutions with the Československé dokumentační středisko nezávislé literatury (The Czecho-Slovak Documentation Centre for Independent Literature) created and led, among others, by Vilém Prečan.

It is worth reminding, that in the 1970s and 1980s activities of exile and domestic independent literary circles were complementary. Jiř́ Lederer, a Czech journalist, engaged in dissent movement after the Soviet invasion, and forced to emigrate in 1980, wrote:

Exile, as a political force, is meaningful only when it is part of the opposition in the homeland, part which, as the historical tradition shows, could temporarily live, and function beyond its territory. We, who live in exile, cannot measure the fullness of our actions according to one's hope of returning home. It is not important, if I return, if I could return. It is important, if I make everything for common return (Lederer, 1982, 132 [trans. U.K.-N.]).

According to Arnošt Lustig, the task of emigrants was to compensate for the shortcomings of the domestic reality, to fill the "gaps in culture":

Exile in certain circumstances $[\ldots]$ is the soul of the body that remained in the homeland. Exile is a voice when the homeland loses its own. Exile is a hand able to move when the homeland is crippled. Exile is a cry that is heard among silenced people, a cry for justice, a cry, which defies prejudice, when the homeland remains defenseless and deprived of its rights (Lustig, 1997, 143 [trans. U.K.-N.]). 
The number of threads, concerning the existence of samizdat and its impact on the Czech independent culture, raised by the authors of the presented publication, cannot be discussed in detail in a short review article. The extensive introduction, the concept of which I have tried to present in previous paragraphs, ends with the chapter devoted to guidelines for readers with information on the structure of the entry section (pp. 97-539). The authors emphasize once again what phenomena of independent culture they had to "ignore" (although many of those are still contextually present in their publication), focusing on the literary side of Czech samizdat (they mention first of all political and religious samizdat, so-called samizdat "mimoedicni" and authorial, v. p. 88). The reader has an opportunity to take a closer look at the enormous amount of work that the authors have had to face, including searching for information about self-printed publications, for which it was characteristic to conceal any details that might indicate people associated with them. The scope of the phenomenon, analyzed by the authors, makes them emphasize that the subject of literary samizdat remains inexhaustible, and, as it turned out, it was impossible to reach all centers or circles that dealt with any independent publishing activity.

The second part of the book contains over three hundred detailed entries devoted to publishers, periodicals, and non-periodical collections in the field of literary samizdat, realized after the communist coup in February 1948 and after the Soviet occupation in August 1968. The structure of the entries includes: a chronological framework, brief description of the publishing house, edition, journal or publication to which the entry relates, information about publishers and closest coworkers, some technical, editorial details (in most cases the entry is accompanied by graphics, illustrating also the visual side of Czech samizdat), more detailed information on publishing production or the content of literary periodicals, and some supplementary information, which regards, for example, additional publishers' activities or later reprints. However, the length and structure of the entries are diversified due to the availability of information and the importance of the phenomenon described. All entries are closed by detailed list of literature, including books, articles, encyclopedic entries, interviews, letters, dissertations, and online resources. ${ }^{8}$

${ }^{8}$ In many cases, fundamental research sources were interviews with witnesses of the era, former publishers and editors who cooperated on preparing the entries. 
Collecting in one place information and details on independent publishing initiatives, which have been already quite well-known and described in the literature is, of course, only one of the great advantages of this publication. Even more important seem to be the entries concerning editions, periodicals, or niche publishers, about which it was difficult to find any information or which have been never mentioned before in scientific studies. The source of information for the authors in that cases were mainly or "only" (in case of 37 entries) interviews and correspondence with people involved in the independent publishing activities. ${ }^{9}$ Presenting these "secondary actors" and showing various cultural phenomena, so far unnoticed in the scientific discourse, is certainly something, that differentiate this book from other publications on Czech independent culture. Its image, well known for years, constructed by the leading figures of the Czech independent literary scene, has a chance to be significantly supplemented; the scale of the phenomenon of samizdat is changing, the authors are also trying to decentralize the

${ }^{9}$ Scientific precision would require mentioning all names, but, it is, of course, not possible. Among the independent publishing initiatives that were so far "ignored" by the scientific literature are here to find as well those very shortly existing or responsible for a small number of editions (such as Reprint xerox created one year before the Velvet Revolution), as those that have lasted for several years and published many editions (e.g. Dílna Vuka a Jitky Kratěnových, distributing not only independent Czech literature, but also cassettes and tapes with independent foreign and domestic music; South Moravian Strojpisná edice pro kamarády [1982-1991], where was published, among others, a unique dictionary of prohibited Czech writers and East European literary personalities [Jakubovi, protože chce védět, 1983]; Edice Vokno [1981-1989], which featured mainly texts of Egon Bondy and the works written by other underground representatives; Vydavatelství Ilji Matouše [1979-1990] - one of the most dynamic private publishing houses of the 1980s, specializing in the publication of folk singers texts. Several entries are also devoted to the series, which provide descriptions of literature published in samizdat and in exile (e.g. Dílna Jaroslava Bednaříka or Spolek nezávislých impresorů), and occasional collective volumes (e.g. Práh [1983], dedicated to the memory of Bohuslav Reynek, LN - Ludvikovy Noviny [1976], published on the occasion of Ludvík Vaculík's $50^{\text {th }}$ birthday, $L N$ [1982], issued on the occasion of the $60^{\text {th }}$ birthday of the literary critic Milan Jungmann or Chvála bláznovství [1979], collection dedicated to Jan Trefulka). Among the publishing initiatives discovered by the authors of the encyclopaedia there are also some periodicals (e.g. "Kain," "Mene tekel fares," "Mírové Materiály" - a quarterly published between 1965-1981 by the clergy of the Czechoslovak Hussite Church, "Noc," "Obálka," "Snad přiště," "Věšák," "Zrcadlo" or "Zvonkohra psího baletu"). Separate entries, full of detailed information, many titles and names, are also devoted to three broader literary phenomena - SF fanzines (pp. 436-443), surrealistic samizdat (pp. 473-478) and so called tramp samizdat (pp. 490-497). 
view of independent publishing by describing less known initiatives from outside the Prague. Recent years have brought many publications offering a new perspective on Czech independent culture of the second half of the $20^{\text {th }}$ century. The time distance allows the authors for bolder analyses and evaluations, as well as a revision of existing beliefs about the function of independent literature in a captive society. Significant anniversaries of historical breakthroughs (such as the August invasion, beginnings of the Charter 77, and finally the Velvet Revolution) become an occasion for further revisions. Passing of the representatives of the generation "responsible for the word" during the communist regime also becomes a sad pretext to bring up this topic again and again. This publication is even more valuable, because its authors have managed to reach the names that are quite unknown and give the floor to those who have never been guests at literary debates or scientific conferences. The authors' research caution, inquisitiveness, perfectionism, visible both in the construction of the entries and in making difficult, often impossible, attempts to reach source materials, as well as the terminological and typological attentiveness resulted in publishing an extremely valuable compendium of knowledge about the independent Czech literary life, and thanks to the processes of systematizing, collecting, supplementing it goes widely beyond the so far available studies.

Besides the chief editor, the encyclopaedia owes its shape to several researchers: Eduard Burget, Marta Edith Holečková, Michal Jareš, Veronika Košnarová, Petra Loučová, Alena Přibáňová, Pavel Šidák and Andrea Vítová. Having in mind the earlier works created under the direction of the literary historian and the expert in Czech independent literature Michal Přibán, the breadth, richness, reliability, and inventiveness of this publication are not surprising. The authors compiled a compendium of knowledge on the Czech literary samizdat, discovered sources that had not been discussed before, brilliantly summarized already existing studies and materials, and, what is probably the most important, reached the people involved in independent self-publishing activities and the Czech dissident movement, who so far stayed in the shadow of the most famous names. The dedication is not surprising as well - who else could become the patron of this compendium, if not Jiří Gruntorád, the founder of the famous library with a collection of samizdat and exile literature Libri Prohibiti, one of the independent publishers in the period of "normalization." 
In one of the surprisingly very few reviews ${ }^{10}$ of this excellent publication, Vladimír Kourril (2019) calls it "the Bible of our samizdat" and "a tribute to the unwavering freedom of spirit." It is hard not to agree with these statements. In the context of the publication, which so precisely reminds of the importance of culture and literature in the life of a captive society, it is also difficult not to mention at the end still very current words, written by Václav Havel in July 1989:

In the beginning of everything is the word.

It is a miracle to which we owe the fact that we are human.

But at the same time it is a pitfall and a test, a snare and a trial.

More so, perhaps, than it appears to you who have enormous freedom of speech, and might therefore assume that words are not so important.

They are.

They are important everywhere (Havel 1989).

\section{References}

Barańczak, S. (2009). Fasada i tyły. In: S. Barańczak. Etyka i poetyka. Kraków: Znak. Fidelius, P. (2009). Literatura oficiální a neoficiálni. Krytický sbornik. Č. 3, p. 2. Quoted after: Jak si vlastně budeme ř́kat, In: Kritický sborník 1981-1989. Výbor ze samizdatových ročníků. Ed. J. Gruntorád, M. Kosák, R. Krumphanzl, K. Palek. Praha: Triáda.

Filip, O. (2008). Konec jedne, ne zcela velkolepé iluze. "Revue Politika" č. 6-7. https://old.cdk.cz/rp/clanky/425/1968-konec-jedne-ne-zcela-velkolepe-iluze/. 30.07.2020.

Havel, V. (1989). Words on Words. Trans. A. G. Brain. https://www.vhlf.org/havel-archives/words-on-words/. 30.07.2020.

Hvížd’ala, K. (2011). Grušova hlídka na Rýnu. Rozhovory z let 1983-2011. Praha: Mladá fronta.

Jagodziński, A. (2000). Nie przestatem być czeskim pisarzem. Rozmowa z Jiřím Gruša. In: A. Jagodziński. Banici. Rozmowy z czeskimi pisarzami emigracyjnymi. Gdańsk: Tower Press, pp. 50-56.

Kouřil, V. (2019). Michal Přibáň a kolektiv: Český literární samizdat 1949-1989. https://www.magazinuni.cz/literatura/michal-priban-a-kolektiv-cesky-literarnisamizdat-1949-1989/. 30.07.2020.

${ }^{10}$ Especially in the context of the nomination for the 2018 Magnesia Litera Award, prestigious Czech literary prize. 
Lederer, J. (1982). Slovo o svědectví i o nás. In: Svědectví Pavla Tigrida. Ed. J. Lederer. Mnichov: Opus bonum, pp. 131-137.

Lustig, A. (1997). Literatura jako osud, In: Literatura. Vězení. Exil. Literature. Prison. Exile. Ed. M. Vacík, L. Ludvíková. Praha: České centrum Mezinárodního PEN klubu, pp. 139-144.

Machovec, M. (2009). The Types and Funkctions of Samizdat Publications in Czechoslovakia 1948-1989. "Poetics Today" no. 1, pp. 1-26. https://doi.org/10.1215/ 03335372-2008-001.

Možny, I. (2009). Proč tak snadno... Některé rodinné důvody sametové revoluce. Sociologický esej. Praha: Sociologické nakladatelství (SLON).

Pithart, P. (1987). Osmašedesátý. Purley: Rozmluvy.

Pithart, P. (2009). Devětaosmdesátý. Vzpomínky a přemyšlení. Krédo. Praha: Academia.

Přibáň, M. et al. (2018). Český literární samizdat 1949-1989. Edice, časopisy, sborníky. Praha: Academia-Ústav pro českou literaturu AV ČR.

Vrba, T. (2001). Nezávislé písemnictví a svobodné myšleni v letech 1970-1989. In: Alternativní kultura. Př́běh české společnosti 1945-1989. Ed. J. Alan. Praha: Nakladatelství Lidové noviny, pp. 265-305. 